\title{
Impact of Cost-Push and Monetary Factors on GDP Deflator: Empirical Evidence from the Economy of Pakistan
}

\author{
Zahoor Hussain Javed (Corresponding author) \\ Department of Economics, GC University \\ Allama Iqbal Road, Faisalabad, Pakistan \\ Tel: +92-300-650-1785 E-mail: zahoorhj@yahoo.com \\ Muhammad Farooq \\ Assistant Professor, Department of Sociology, GC University \\ Faisalabad, Pakistan. \\ E-mail:farooqkharal@hotmail.com
}

Maqsood Hussain

Assistant Professor of Agricultural, University of Agricultural

Faisalabad, Pakistan.

Abdur-Rehman Shezad

Lecture in Rural Sociology, University of Agricultural

Faisalabad, Pakistan

Safder Iqbal

Lecturer in Economics, GC University

Faisalabad, Pakistan.

Shama Akram (Note 1)

Department of Economics, GC University

Faisalabad, Pakistan

Received: August 30, 2010

Accepted: February 11, 2011

doi:10.5430/ijfr.v2n1p57

\begin{abstract}
The central objective of this paper is to find the validity of cost-push and monetary factors on GDP deflator through empirical analysis. The empirical analysis has been conducted by using the technique of Ordinary Least Square using annual data for the period from 1971-72 to 2006-07. Before applying OLS the stationarity of the data was checked by Augmented Dickey Fuller (ADF) test. Regression analysis proves that both cost-push and monetary factors are influenced on wholesale price index. The monetary variables have significant impact on GDP deflator.. There is no single remedy to control the raise of wholesale price index. Government should adopt multipurpose strategy such as improvement in tax and revenue structure, improving fiscal and monetary discipline, removing supply side disruptions, eradication of anti-competitive market practice.
\end{abstract}

Keywords: Cost-push, Monetary policy, GDP deflator, Pakistan 


\section{Introduction}

\subsection{Cost-push shocks and monetary policy}

The main objective of this study is to present comprehensive and updated concept of the composition of cost-push shocks, and monetary policy that are compulsory to solve the important economic problems facing Pakistan like inflation, low wage rate, low real gross domestic product and to recommend some solutions to curb these troubles. Akhtar (2006) says that consumer price Index is the important tool of measuring price changes of fixed basket of goods and services. In Pakistan first time, the consumer price index was determined as base for manufacturing employees in metropolises of Lahore, Karachi and Sialkot in 1948-49. 1959-60, 1969-70, 1975-76, 1980-81 and 1990-91 are taken as base years for the consumer price index. Currently, consumer price index is determined on the fixed price of year 2000-0. The study of consumer price index is reported that inflation rate during the fiscal year 2000-01, 2001-02 4.41 and 3.54 respectively. Similarly, in 2002-03 it dropped down to 3.54. Nevertheless, in fiscal years 2003-04 and 2004-05 inflation rate is again raised to 4.57 and 9.28 respectively. Nonetheless, by the mid of the October, 2006, inflation rate is reported 8.43 percent.

\subsection{Cost-push shocks}

Cost-push inflation is an inflation, which is occurred due to raise of price of goods and services but this can not be change with any other appropriate substitution. Cost-push factors activate through the supply-side of the economy by increasing the unit cost of production, so that real output or GDP contraction can create inflation (Gaomab II, 1998). The cost-push inflation theory emphasizes the fact that rise prices due to the increasing cost of production. Prices are pushed up by rising costs and these costs are passed along to the consumers in the form of higher prices. Wages are pushed up by trade union's bargaining power (Makochekanwa, 2007).

Substantial debate is still going on among economists regarding the causes of inflation and concerning the appropriate policy to curb inflation. Classical economists state that money is a main tool to bring change in status of economy, therefore price level of goods and services proportionally rise due increase in the money supply, but real income, real interest rate and level real economic activities remain unchanged, consequently economy remains at full employment. Neo-Classicists also consider the excessive increase in money supply as the cause of inflation. Monetarists view money supply as the only factor creating inflation through the demand channel and they give more importance to monetary policy to stabilize the economy. According to Keynes when there is under unemployment in the economy an increase in the money supply leads to an increase in aggregate demand, output and employment in short-run but in long -run there is no effect of money. If the money supply increases beyond the full employment level, output causes to rise and prices rise in proportion with the money supply. He also argues that it is the costs of such a recession that likely cause governments and central banks to allow a supply shock to result in inflation (Jhingan, 2003).

Milton gives his views against the perception of inflation which is raised due to increase in cost of goods and services because he suggest that without cooperation of government of that time and its central bank which is raised money supply. He further explores that if growth rate of money supply remains constant, then raise of the cost of a good and service reduces the money available for other goods and services, and consequently the price of a few other goods fall and nevertheless, rise of prices take place in those goods whose prices have raised (Majumder, 2006). Cost-push inflation is usually regarded as primarily wage-push inflation because wages usually constitute the greater part of total costs. Powerful trade unions force employers to grant wage increases considerably in excess of increases in the productivity of labor and these wage increases lead to increase the cost of production of commodities. In this way wage-push inflation in a few sectors of the economy soon leads to inflationary rise in the prices in the entire economy. Notwithstanding, the GDP deflator is a measure of the level of prices of all new, domestically produced, final goods and services in an economy. GDP stands for gross domestic product, the total value of all final goods and services produced within that economy during a specified (Jhingan, 2003).

Some economists raise some objections to this argument of wage-push inflation. According to them some unions are powerful and can influence the money wages but others possess little or no bargaining power. One difficulty in determining the impact of unionism on wages is that they tend to increase in the absence of unions. Therefore it is difficult to determine how much of a given wage increase is due to the union activity and how much is owing to the market forces. In an economy experiencing demand-pull inflation, money wages increase: they also increase if productivity increases. Despite these pitfalls there is evidence to suggest that unionism have raised the wages of union labor relative to the nonunion labor (Edgmand, 1985). 
Ackley (1968) states that the alternative of cost-push theory is that cost-push inflation is caused when the monopoly power of big business firms enables them to raise prices. Powerful corporations presumably can raise prices to increase their profits. Each time the corporations raise prices the cost of living goes up. Workers then demand higher wages to make up for the decline in their standard of living and thereby give the corporations an excuse to raise prices again. Again just as labor unions are prerequisite to wage-push inflation, so the existence of imperfectly competitive markets in the sale of goods and services is a prerequisite to profit push inflation. In such a situation these firms are able to "administer prices" of their products. When such process becomes wide spread it leads to inflation, which is also called administered-price theory of inflation or price-push inflation or sellers' inflation or market power inflation.

Supply-shocks are also the causes of cost-push inflation. A supply shock is an event that rapidly changes the price of a commodity. It may be caused by a sudden increase or decrease in the supply of a particular good. Adverse supply shocks are typically events that push up the costs of production. A negative supply shock can cause stagflation due to a combination of raising prices and falling output (Mankiw, 1997). The most popular, example of supply shocks is oil prices. Organization of Petroleum Exporting Countries (OPEC), in a brief period during 1973 and 1974 doubled and then redoubled the prices, which importers had to pay for oil. In 1979-1980, oil prices were more than doubled again (Wonnacott and Wonnacott, 1982). The domestic price level cannot remain resistant to external price shocks. The economies have to take the foreign prices as given. The external price shock is further exacerbated when the prices of imported commodities used as an input in the domestic products are measured in local currency. If the external price shock is accompanied by devaluation of local currency or a higher tariff rate, then it is translated into the prices of domestic products because of increasing costs (Hansen et al. 1995).

\subsection{Monetary policy}

The second part of the research title is monetary policy. Most macro economist state that if the growth rate of money supply is higher than the growth rate of economy, then this situation is called inflation. The Monetarists Model developed by Friedman in 1968 and empirically tested by Schwartz in 1973 simply asserted that the prime factor explaining the current rate of 'secular price change' is the past behavior of money to output ratio (Morley, 1984). Monetary policy is a policy which is concerned with the regulation of the quantity, cost and allocation of money and credit in the economy in order to attain a set of objectives oriented towards the growth and stability of the economy. It is a mechanism that has serious implications for economic development of the country, as it helps to determine how and where resources are to be allocated in the different sectors of the economy (Zaidi, 2005). Monetary policy is conducted and implemented by the central bank of the country. Central bank controls all commercial banks and other semi government banks. The main objectives of Central bank are to control money supply with tools of monetary base and high powered money. So central bank decrease or increase money supply to bring stabilization in the economy of the country (Jhingan, 2003). The objectives of the monetary policy are the price stability, to raise the level of employment, stable economic growth, interest rate smoothing, and exchange rate stabilization (Malik, 2007).

Minshki (2004) provides an excrescent reconciliatory remark in that sustained cost- push inflation is also a monetary phenomenon because it cannot occur without the acquiescence of the monetary authorities to a higher rate of money growth. Although theoretically we can distingui8sh between monetarist and structuralism inflation, it is much harder to do so in application since both types of inflation are associated with high rates of money growth. Monetization of fiscal deficits leads to higher inflationary pressures to the economy. Monetization of the fiscal deficits in frequently is the major cause of excessive monetary expansion in developing countries like Pakistan. This is because of war, natural disaster, major political and economic upheavals the structural weakness of revenues as well as under- developed capital markets and low private savings. Main indicator of domestic inflation is the borrowing which is taken from the banking system. Budget deficits are directly related to general price level; it means that they both moves in same direction through the expectations of publics and aggregates monetary.

Jongwanich and Park (2008) examined the relative importance of different sources of inflation in developing Asia. A vector auto regression model was estimated for the period 1996Q1-2008Q1. The variable they used was oil and food prices inflation rate exchange rate and output gap. They found that Asia's inflation was largely due to the inflation expectation and excess aggregate demand. They also described that the sheer speed of the rise in commodity prices and hence input costs gave a great deal of credibility to the cost- push diagnosis.

Hassan and Alogeel (2008) investigated the factors that affected inflation in the region by examining the inflationary process in Saudi Arabia and Kuwait .According to the authors external cost-push factors played a dominant role on the dependence of the Saudi and Kuwait economies on imports and foreign labor to meet domestic demand of tradable and nontaxable. 


\section{Data and Methodology}

The data for the macroeconomic variables such as GDP deflator, gross domestic product (GDP), exchange rate (EXR), wheat support price (WSP) annual wage in the perennial industries (WAG), value of imported raw material (RAW), were taken from the International Finance Statistics (IFS) and various issues of Economic Survey of Pakistan. Nevertheless, dummy variables (assume the value of 1 when the natural disaster occurs and otherwise 0 ) is also used to find impact of disaster on macroeconomic variables. The impact of cost-push factors on consumer price index (CPI) in Pakistan is covering the period of 1971-72 to 2006-2007. An econometric analysis based on ordinary least square (OLS) is used to analyze the trends and patterns, GDP deflator will be taken as dependent variable, while gross domestic product (GDP), exchange rate (EXR), wheat support price (WSP) annual wage in the perennial industries (WAG), value of imported raw material (RAW), are taken as independent variables.

Model.1: can be expressed as:

$\mathrm{GDPD}=\beta 0+\beta_{1} \mathrm{EXR}+\beta_{2} \mathrm{WSP}+\beta_{3} \mathrm{WAG}+\beta_{4} \mathrm{RAW}+\beta_{5} \mathrm{GDP}+\beta_{6} \mathrm{D}+\mu$

Where $\beta_{1}, \beta_{2}, \beta_{3}, \beta_{4}, \beta_{5} \beta_{6}>0$

GDPD $=$ GDP Deflator

$\mathrm{EXR}=$ exchange rate

WSP $=$ wheat support price

$\mathrm{WAG}=$ wage in the perennial industries

RAW $=$ value of imported raw material

$\mathrm{D}=$ Dummy variable

The Augmented Dicky-Fuller (ADF) and Philips Perron (PP) unit test are used to detect the level of stationary. The results are reported in Table 1.

The null hypothesis is that the series is non-stationary or contains a unit root. The rejection region of a null hypothesis for both ADF and PP is based on Mackinnon critical values.

$<$ Table1 about here $>$

First model is estimated and the results of the estimation are reported as under.

$$
\mathrm{GDPD}=1.38+0.43 \mathrm{EXR}+0.04 \mathrm{WSP}+1.8 \mathrm{WAG}+1.34 \mathrm{RAW}+0.75 \mathrm{GDP}+1.32 \mathrm{D}
$$

$$
\text { R-Squared }=0.69
$$

Adj. R-Squared $=0.62$

F-statistic $=9.85$

Prob. $($ F-statistic $)=0.00$

Results of the model are somewhat satisfactory and signs of the coefficients are supporting the previous research findings. The coefficients of all variables in above regression are statistically significant except GDP and wheat support price which are not statistically significant even at $10 \%$ level of significance. The sign of the exchange rate shows that there is positive relationship between exchange rate and wholesale price index. The justification for this positive relationship is that as the exchange rate increases (devaluation or depreciation of Pakistani rupee) the inflation increases because the imports become expensive which switch out aggregate demand of domestic and foreign residents towards domestic goods, consequently, costs of production are raised. The slope of exchange rate suggests that 1 unit increase in exchange rate leads to 0.43 units increase in GDP deflator. The wheat support price has also positive relationship with GDP deflator but is not statistically significant. Its slope coefficient indicates that 1 unit increase in wheat support price leads to 0.04 units increase in GDP deflator. Annual wage affects GDP deflator in positive manner as indicated by the sign. As the wages increase the costs of the production increase and producers shift these higher costs on the consumers in the form of higher prices. The prices of imported raw material have strong impact on GDP deflator and its positive sign suggests that as the prices of raw material increase in the international markets the domestic price level also increases. Real GDP has positive sign but insignificant relationship with GDP deflator. The positive sign indicates that as the supply of goods and services increases level of GDP deflator increases. The justification of the positive relationship of the dummy variable with GDP deflator is that when the natural calamities (such as floods, droughts, earthquakes etc) occurs the production of various commodities fall and there shortage leads to higher prices of these 
commodities. The results are consistent with the result of Hassan et.al (2008). The value of $\mathrm{R}^{2}$ is 0.687 which shows that about $68.7 \%$ variation in wholesale price index is explained by the cost-push factors and wholesale price index. The value of the adjusted $\mathrm{R}^{2}$ is 0.623 . F-value indicates that model is proper fitted to the data. This can be verified from the normal plot of the residuals which shows that residuals are normally distributed. The Breusch- Godfrey test is applied to detect the serial correlation in the data. The results are given in the Table 2 which shows that there is no serial correlation in the data.

$<$ Table 2 about here $>$

Model 2: The second model is as below:

$$
\begin{aligned}
& \mathrm{GDPD}=\alpha_{0}+\alpha_{1} \mathrm{M}_{1}+\alpha_{2} \mathrm{M}_{2}+\alpha_{3} \mathrm{LM}+\alpha_{4} \mathrm{LCPI}+€ \\
& \quad \alpha_{1,} \alpha_{2}, \alpha 3 \text {, and } \alpha_{4}>0 \\
& \text { WPI }=\text { Wholesale price index } \\
& \mathrm{M}_{1}=\text { Narrow money supply } \\
& \mathrm{M}_{2} \text { = Broad money supply } \\
& \mathrm{LM}=\text { Lag value of broad money supply } \\
& \mathrm{LCPI}=\mathrm{Lag} \text { value of CPI } \\
& \text { GDPD = } 1.43+0.8 \mathrm{M}_{1}+1.3 \mathrm{M}_{2}+0.85 \mathrm{LM}+0.96 \mathrm{LCPI} \\
& \quad(1.092)(0.077) \quad(1.13) \quad(4.441) \\
& \text { R-Squared }=0.795
\end{aligned}
$$

Adj. R-Squared $=0.767$

F-statistic $=28.16726$

Prob. $($ F-statistic $)=0.000$

Results of the model are somewhat acceptable and signs of the coefficients are supporting the previous research conclusions. The slope of the Lag value of broad money supply M and value of GDP deflator in above estimated regression are statistically significant, while the coefficients of the variables $\mathrm{M}_{1}$ and $\mathrm{M}_{2}$ are not statistically significant even at $10 \%$ level of significance. The sign of $\mathrm{M}_{1}$ shows that there is positive relationship between narrow money supply and GDP deflator. The broad money supply $\mathrm{M}_{2}$ has positive but insignificant relationship with GDP deflator Expectations also play dominant positive role in creating inflation as revealed by the sign of LCPI. The justification for this positive relationship is that when people expect higher inflation they demand for more money. They demand for more money to compensate for expected increase in prices and also take more credit from the banks. Speculation in asset prices increases and hoarders, profit seekers and renters become active in expectation of higher prices in the future. All this leads to climb of GDP deflator. The results are consistent with that reported by Qayyum (2006), and Makochekanwa (2007).

The value of the $\mathrm{R}^{2}$ is 0.80 which suggests that about $80 \%$ variation take place among variables. Consumer Price Index is due the monetary factors and remaining $20 \%$ is due to other factors. The value of the adjusted $\mathrm{R}^{2}$ is 0.77 . The value of $\mathrm{R}^{2}$ and $\mathrm{F}$-value shows that model is proper fitted to the data. This can be verified from the normal plot of the residuals which shows that residuals are normally distributed.

The Breusch-Godfrey test is applied to detect the serial correlation in the data. The results are given in the Table 2 which shows that the null hypothesis i.e. there is no serial correlation in the data.

$$
<\text { Table } 3 \text { about here }>
$$

\section{Conclusion}

The central objective of this research is to examine the validity of the cost-push and monetary factors on GDP deflator through empirical analysis using annual data from 1971-72 to 2006-07. Results of the model are quite satisfactory and signs of the coefficients are supporting the previous research findings and validity of the Results of the model is quite satisfactory and signs of the coefficients are supporting the previous research findings. The coefficients of all variables in above regression are statistically significant except GDP and wheat support price which are not statistically significant even at $10 \%$ level of significance. The sign of the exchange rate shows that there is positive relationship between exchange rate and wholesale price index. The wheat support price has also positive relationship with GDP deflator but is not statistically significant. Annual wage affects GDP deflator in positive manner as indicated by the sign. As the wages 
increase the costs of the production increase and producers shift these higher costs on the consumers in the form of higher prices. The prices of imported raw material have strong impact on GDP deflator and its positive sign suggests that as the prices of raw material increase in the international markets the domestic price level also increases. The results are consistent with the result of Hassan et.al (2008).

Results of the model are somewhat acceptable and signs of the coefficients are supporting the previous research conclusions. The slope of the Lag value of broad money supply M and value of GDP deflator in above estimated regression are statistically significant, while the coefficients of the variables M1 and M2 are not statistically significant even at $10 \%$ level of significance. The sign of M1 shows that there is positive relationship between narrow money supply and GDP deflator. The broad money supply M2 has positive but insignificant relationship with GDP deflator Expectations also play dominant positive role in creating inflation as revealed by the sign of LCPI. The justification for this positive relationship is that when people expect higher inflation they demand for more money. They demand for more money to compensate for expected increase in prices and also take more credit from the banks. Speculation in asset prices increases and hoarders, profit seekers and renters become active in expectation of higher prices in the future. All this leads to climb of GDP deflator. The results are consistent with that reported by Qayyum (2006), and Makochekanwa (2007).

In nut shell, there is no single remedy to control raise of wholesale price index. Government should adopt multipurpose strategies such as improvement in tax and revenue structure, improving fiscal, monetary policies and structural adjustments policies, removing supply-side disruptions, eradication of anticompetitive market practices.

\section{References}

Ackle, G. (1968). Macroeconomic theory. The Macmillan Company, New York .pp 439-452.

Culbertson, J.M (1978). Money and Banking. $2^{\text {nd }}$ Edition. Mc Graw -Hill Publishing Company Ltd .New Dehli. pp. 37-39.

Edgmand, M.R. (1985). Macro Economic Theory and Policy $.2^{\text {nd }}$ Edition. Prentice Hall of India pte. Ltd New Dehli India .pp. 252-257.

Dlamini, A.A Dlamini and T. Nxumalo (2001). A Co integration Analysis of The Determinants of Inflation in Swaziland. Central Bank of Swaziland Publications, Mbabane Swaziland, pp.1-37.

Gaomab II, M.(1998). Modeling Inflation in Namibia .Occasional Paper No.1 ,Research Department ,Bank of Namibia .pp.1-30.

Hansen, G., and J.R. Kin (1996). Money and Inflation in Germany : A Cointergration Analysis .Empirical Economics 21 ,pp. 601-616. doi:10.1007/BF01180704, http://dx.doi.org/10.1007/BF01180704

Hasan, M.and H,Alogeel(2008). Understanding The Inflationary Process in The GCC Region : The Case of Saudia Arabia and Kuwait .IMF Working Paper, WP/08/193.

Jhingan, M.L.(2003). Macroeconomic Theory $.11^{\text {th }}$ Edition Varinda Publication Ltd. Dehli pp. 317-344,42-478 , 616-618.

Khan ,A.A .S.K.H.Bukhari and Q.M.Ahmad (2007). Determinants of Recent Inflation in Pakistan Social Policy Development Center (SPDC) Research Report No. 66.

Khan, A.H. M.A. Qasim (1996). Inflation in Pakistan Revisited. The Pakistan Development review, Vol.35 No.4, pp.747-759.

Majumder, M.A (2006). Inflation I Bangladesh: Supply Side Perspective. Policy Notes Series: PN0705, Research Department, Bangladesh Bank: Policy Analysis Unit .pp. 1-10.

Makochekanwa .A. (2007). A Dynamic Enquiry into the Causes of Hyperinflation in Zimbabwe. Department of Economic Working paper Series, WP: 2007 -10 University of Pretoria, South Africa.pp.1-29.

Malik, W.S (2007). Monetary Policy Objective in Pakistan: An Empirical Investigation. PIDE Working Papers, Islamabad .pp. 1-25.

Mankiew,N.G (1997). Macroeconomic, $3^{\text {rd }}$ Edition Worth Publishing in .New York .pp. 108, $362,487$.

Morley, S.A (1984). Macroeconomic .Holt- Saunder International Edition , Japan .pp. 97- 112, 195 -220.

Petrovic, P.and Z . Mladenovic (2005). Econometric Modeling of Inflation in Serbia. Faculty of Economics. Quarterly 
Monitor 1, University of Belgrade. Pp.50-59.

Qayyum, A. (2006). Money Inflation, and Growth in Pakistan .The Pakistan Development Review, Vol .45, No. 2 pp. $203-212$.

Wonnacott, P.and R. Wonnacott (1982). Economics. $2^{\text {nd }}$ Edition. McGraw -Hill International Book Company, New Dehli , India .pp.229 -231 , 277-279.

Zaidi, S.A. (2005). Issues in Pakistan Economy, $2^{\text {nd }}$, Edition. Oxford University Press Korangi Industrial Area, Karachi, Pakistan .pp.283-307.

\section{Notes}

Note 1. This paper is taken from thesis of Shama Akram

Table 1. Results of the unit roots and Philips Perron tests

\begin{tabular}{|c|c|c|c|c|}
\hline ADF & & & PP & \\
\hline $\begin{array}{c}\text { Variable } \\
\mathrm{s}\end{array}$ & Level & Ist diff & Level & Ist diff \\
\hline EXR & 0.29 & 3.25 & 0.59 & 3.35 \\
\hline WSP & 2.17 & 5.54 & 2.47 & 5.64 \\
\hline GDP & 7.74 & 9.78 & 7.94 & 8.78 \\
\hline RAW & 2.56 & 3.34 & 2.76 & 3.64 \\
\hline WAG & 3.44 & 3.10 & 3.84 & 3.50 \\
\hline M1 & 5.76 & 2.83 & 5.96 & 2.93 \\
\hline M2 & 4.65 & 3.34 & 4.95 & 3.64 \\
\hline CPI & 1.86 & 3.56 & 2.96 & 3.56 \\
\hline WPI & 2.67 & 8.31 & 2.87 & 8.51 \\
\hline DGDP & 3.54 & 7.34 & 3.54 & 7.84 \\
\hline
\end{tabular}

Critical value: $-3.64,-2.60,-1.95$ at $1 \%, 5 \%, 10 \%$ respectively

Table 2. Breusch-Godfrey serial correlation LM test for model 1

\begin{tabular}{|l|l|l|l|}
\hline F-statistic & 1.499 & Probability & 0.240 \\
\hline Obs:R-squared & 5.366 & Probability & 0.146 \\
\hline
\end{tabular}

Table 3. Breusch-Godfrey serial correlation LM test for model 2

\begin{tabular}{|l|l|l|l|}
\hline F -statistic & 0.172 & Probability & 0.681 \\
\hline Obs:R-squared & 0.208 & Probability & 0.648 \\
\hline
\end{tabular}

